\title{
Steady-State and Vibration Analysis of a WindPACT 1.5-MW Turbine Blade
}

\author{
Enas AbdZaid Khazem \\ Teaching Assistant \\ University of Baghdad \\ Department of Energy Engineering \\ Iraq
}

Oday Ibraheem Abdullah

Assist. Prof. Dr.-Ing

University of Baghdad

Department of Energy Engineering

Iraq

Laith A. Sabri

Research Associate Case Western Reserve University Department of Physics

The aim of this paper is to study the stresses and deformations of a wind turbine blade under the steady-state load condition in addition to investigating the vibration characteristics (natural frequencies and mode shapes). The selected wind turbine blade is WindPACT 1.5-MW with upwind horizontal axis that has three blades of a length $34.125 \mathrm{~m}$ and rotor diameter $70 \mathrm{~m}$. The wind turbine blade model was made using SOLIDWORKS software then exported to ANSYS Workbench. Finite element analysis has been used to achieve the numerical simulation of the wind blade. The steady-state behavior of the selected wind turbine blade was investigated deeply at the rated output power (maximum rotational velocity 20.5 RPM). In this research paper two different isotropic materials [structural steel (Blade A) and Al 2024 (Blade B)] were selected for different parts of the blade to spotlight the effect of materials type on the stresses, deformations and natural frequencies of wind turbine blade. The results presented the von-Mises stresses, total deformations and the ten first natural frequencies of WindPACT 1.5-MW wind blade. It was found that the wind blade response was improved when used the Al 2024 material instead of the structural steel.

Keywords: stress analysis; steady-state load condition; vibration analysis; wind turbine blade.

\section{INTRODUCTION}

Wind power is one of the most sustainable of renewable energy sources when the environmental matters such as climate variation, acid rain and imbalance in natural resources are increased because of the use of fossil fuel like gas, oil and coal for generating power. Wind power is energy with a clean source. Wind power is an alternative to fuel. Many countries used wind energy for these reasons. Figure 1 shows the increasing use of wind energy in recent years. The blades must be solid to avoid the towers hitting when they deflected by loads of wind. For any particular material, the inner structure will obtain the stiffness and strength of the wind turbine blades. At the same time when we seeing the strength and weight turbine blades rigidity play an important role to obtain the cost and saving from the fatigue failure. In overall, it's needed to strong and light materials in order to reduce the total weight of the system of wind turbine [1].

Rasuo et al. [2] developed the new wind turbine rotor blades by using composite materials. It was proved based on the standard testing of blades that the developed model of blade is reliable and can be used in the wind farm. Numerical and experimental approaches were used to analyze the new model of wind turbine. Where the experimental covered different types of tests such as static, vibratory and fatigue, while the design of

Received: October 2018, Accepted: December 2018 Correspondence to: Assist. Prof. Dr. Oday I. Abdullah University of Baghdad, Baghdad-Aljadria 47024, Iraq E-mail: oday.abdullah@tuhh.de doi: 10.5937/fmet1901195K

(C) Faculty of Mechanical Engineering, Belgrade. All rights reserved the blades was achieved by using CATIA designing system and Gerber Garment cutter system. This wok presented the full details about how to design, manufacture and test the wind blade by using the composite materials and how to overcome the complexity of the design of the wind blade.

1.5-MW WindPACT turbines consist of three fibreglass blades (horizontal axis) is shown in Figure 2. The hub is linked to the main shaft, which turns into a system with multi-stage of gears. Gears raise the rate of rotation and direct the kinetic energy obtained from the wind to a double feed electric machine, where it is translated into electrical energy [3].

The blades angle and the direction of the turbine faces are controlled in both the pitch electric and the yaw system. The maximum generator output of this kind of wind turbine is 1.5-MW. The alternator and gearbox are included in the nacelle that is high isolated in order to reduce noise emissions [4].

Steady-state and dynamic behaviour were studied for different types of rotating blades. The results of these researchers focused on the stresses and natural frequencies of the damaged and undamaged rotating blades by using numerical and experimental approaches [5-9].

Rasuo [10] developed a new test procedure to study the fatigue problem of the composite laminated materials helicopter blades (full-scale). This work presented the full details of the analyses the behaviour based on the fatigue testing of the main rotor blades. The light multipurpose helicopter propulsion system and the heavy transport helicopter tail rotor blade which composite laminated materials were used in the analysis. 
The applied test loads covered wide range, steady centrifugal, vibratory chordwise bending, vibratory flapwise bending, and vibratory torsional pitch motion. Also, Rasuo [11] studied the resistance of the heavy transport helicopter tail rotor blade (composite material) after the ballistic damage by the bullet of 7.9-mm calibre shoulder weapons. It was investigated the Penetrating damages which happened in the root part of the tail rotor blade. The test was made for the tail rotor helicopter blades (non- damaged and damaged) under the dynamic working conditions. The results of these papers are considered essential to understand the weakness and the resistance of the helicopter tail rotor blade after ballistic damage made by the bullet of shoulder weapons.

Vibration analysis is essential to analyzing the structures to avoid failure. It provides data around shape modes and natural frequencies. Natural frequencies are critical to a set structure. If a frequency force is applied to the structure, it can cause catastrophic failure by raising the deflections. It should notice that that the mode shape and natural frequency connected to the apply frequency and propagation force. When the real resonance occurred for enough time, the blade structure subjected to a high load, which leads to failure. Therefore, the designers of wind turbine blades should avoid the resonance to the blades during the range of working [12].

Ponta et al. [13] presented a new method that called the Dynamics Rotor Deformations-Blade Element Momentum model (DRD-BEM), which is taken into account the effect of the complex deformation of the rotor structure modes. Ponta used a model of response of the structural composite material blades, which lets the total illustration of the composite blade deformation modes at a decreased computational cost Results the used case for the NREL-5MW Turbine. The results from this paper were the influence of the joined modes of deformation varying the arrangement of the wind blade segments, which causes the aerodynamics force that produced the driving torque to drop with deformation growing as the wind speed rises.

Liu et al. [14] studied the effect of vibrations blade on the aerodynamic loads, the stall dynamic features of airfoil S809 airfoil undertaking different kinds of motion were examined using (CFD) analysis. The effect of vibrations on the aerodynamic loads on the blade of a 5MW wind turbine was examined using the Blades Element-Momentum (BEM) theory. Liu concluded that, for large-scale wind turbines it is required to assume the blade vibrations in the aerodynamic analysis to find an optimal structural strength and control design system.

Rasuo et al. $[15,16]$ presented the developed method to find the optimum positions of the single wind turbines within the wind farms which installed in the arbitrary configured terrains. The objective of this work is to obtain the maximum production effectiveness. It was use the genetic algorithm to achieve the optimization technique. It was assumed that the wind turbine works under unsteady condition, where the blade modeled as a vortex lattice and the free-wake type airflow behind the blade. Two different fitness functions were assumed; the first one is the total energy obtained from the farm while the second one is the total investments in a single wind turbine. Furthermore, the optimization analysis extended to involve the total number of turbines as an additional variable. It was tested several different terrain configurations based on the proposed procedure to study the performance of each case

Krishnamurthy and Sesharao [17] investigated the dynamic behaviour and performance of the rotating blades using different methods. In there paper they focused on the dynamic of a horizontal axis wind turbine blade (airfoil NACA 63415) which exposed to centrifugal load, aerodynamic and gravity loads. The effects of the angular speed and tip speed ratio on the natural frequencies were considered in this research.

The aim of this work is to calculate the total deformations, Von-Mises stresses and tenth first natural frequencies for the wind turbine blade (WindPACT 1.5 -MW). The models were built by using SOLIDWORKS and then the models exported to ANSYS/Workbench software to obtain the steady-state and dynamic responses. It was selected two types of isotropic materials, structural steel (Blade A) and Al 2024 (Blade B). This paper presents the full details to build the mathematical model of the wind turbine and find the results deformations, stresses and natural frequencies.

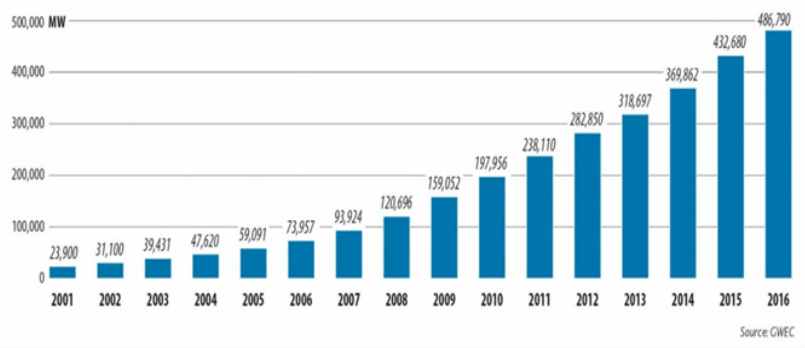

Figure 1. The Global accumulative installed wind capacity 2001-2016 [1]

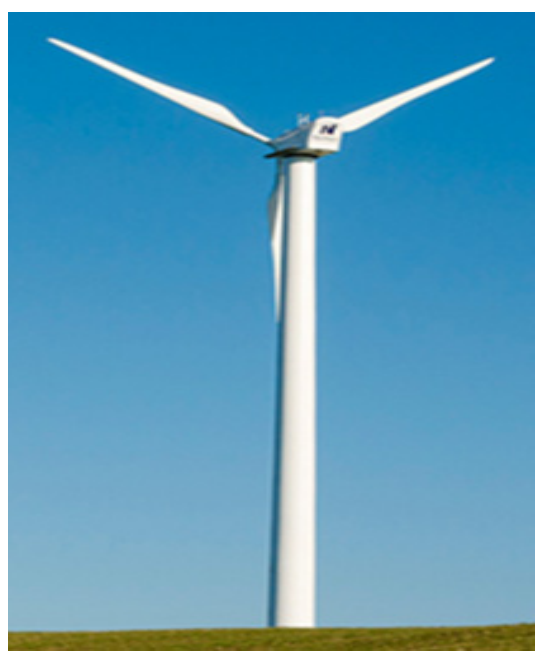

Figure 2. Wind turbine (WindPACT 1.5-MW) [4].

\section{MODELLING OF THE WIND TURBINE BLADE}

In this work, SOLIDWORKS software was used to build the 3-dimensional model of a wind turbine blade with a length of $34.125 \mathrm{~m}$ and with a diameter of rotor $70 \mathrm{~m}$. The thickness of the outer surfaces was assumed a vary with the length of the blade, the thickness started at 
the hub (root of the blade) with $30 \mathrm{~mm}$ (maximum thickness) and decreases linearly with the blade length to the minimum value $(10 \mathrm{~mm})$ at the blade tip.

The steps needed to draw the wind turbine blade in SOLIDWORKS software are to start drawing the cylinders based on the data of this type of wind blade. The next step is to get the airfoils data of the selected wind turbine blade from airfoil tools, and then we can draw each airfoil. The final step is to turn the above steps into a three-dimensional body through special instructions in the SOLIDWORKS.

Figure 3 shows a model built by using SOLIDWORKS, while Table 1 shows the specifications and dimensions of wind turbine [18].

Table 1. Specifications and dimensions of WindPACT 1.5MW HAWT

\begin{tabular}{|c|c|}
\hline Rating power (MW) & 1.5 \\
\hline Rotor diameter (m) & 70 \\
\hline Hub height $(\mathrm{m})$ & 84 \\
\hline Maximum angular velocity of the rotor (rpm) & 20.5 \\
\hline Hub overhang $(\mathrm{m})$ & 3.300 \\
\hline Tower base diameter $(\mathrm{m})$ & 5.663 \\
\hline
\end{tabular}

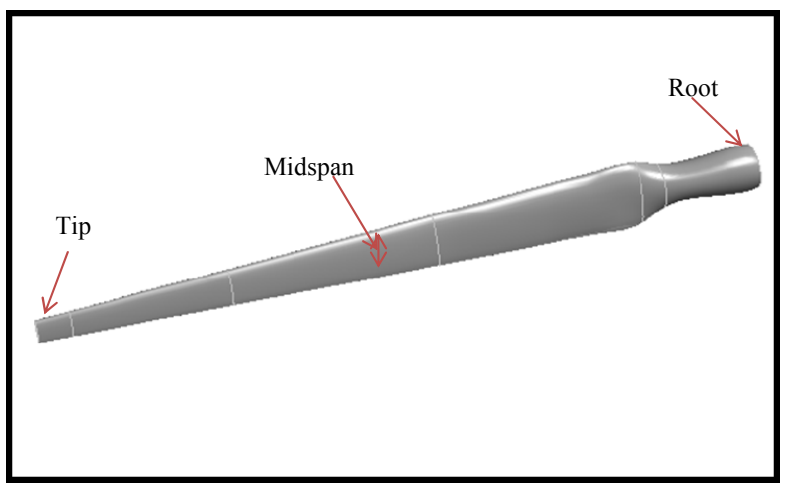

Figure 3. SOLIDWORKS model of wind turbine blade (WindPACT 1.5-MW, upwind HAWT)

\section{FINITE ELEMENT FORMULATION}

ANSYS workbench was used to find the stresses and vibration analysis of the turbine blade. The model of the wind turbine blade was built using SOLIDWORKS, exported to ANSYS/Workbench to start the finite element simulation.

The numerical work in this paper covers the steadystate and vibration problems of the wind turbine blade. The behaviour of the steady-state of wind turbine blade was investigated due to centrifugal force. It was assumed that the critical case, when the blade works, is at the rated output power (maximum rotational velocity 20.5 RPM).

The boundary condition of the wind turbine blade is similar to the cantilever beam, where the blade is fixed at the root and is free at the tip as shown in Figure 4.

Table. 2, lists the mechanical properties of the selected materials. Figure 5 shows the flowchart that explained the processes to build 3-dimensional model of the wind turbine blade and how to export the model to ANSYS Workbench to start the finite element simulation and obtain the desired results.

In order to obtain the results with a high accuracy, the optimal mesh was selected based on the standard mesh test for both cases static structure analysis and in modal analysis, the selected element size for meshing was $0.077 \mathrm{~m}$ with quadrilateral element type for two different type of blade used. The number of elements was 16688 Figure 6 illustrates the selected mesh that used for steady-state and vibration analysis.

The steady-state response of shell (wind turbine rotor blades) may be obtained from Eq. (1) by putting inertia forces and damping forces equal to zero [9], this equation called Steady-State Loading equation:

$$
[K]\{U\}=\{R\}
$$

where $[K]$ is the stiffness matrix of the system and the $\{U\}$ is displacement vector and $\{R\}$ is load vector, usually the centrifugal force.

If any flexible structures are disturbed in an appropriate manner, the structure can be made to oscillate harmonically. This movement oscillatory is a characteristic property of the structure and it depends on the hardness and the distribution of mass in the structure.

Table 2. Mechanical properties of the selected materials of wind turbine blades [19]

\begin{tabular}{|c|c|c|}
\cline { 2 - 3 } \multicolumn{1}{c|}{} & Structural steel & $\mathrm{Al} 2024$ \\
\hline $\begin{array}{c}\text { Density } \\
\left(\mathrm{Kg} / \mathrm{m}^{3}\right)\end{array}$ & 7850 & 2780 \\
\hline $\begin{array}{c}\text { Modulus of elasticity } \\
(\mathrm{GPa})\end{array}$ & 200 & 73 \\
\hline Poisson ratio & 0.3 & 0.33 \\
\hline
\end{tabular}

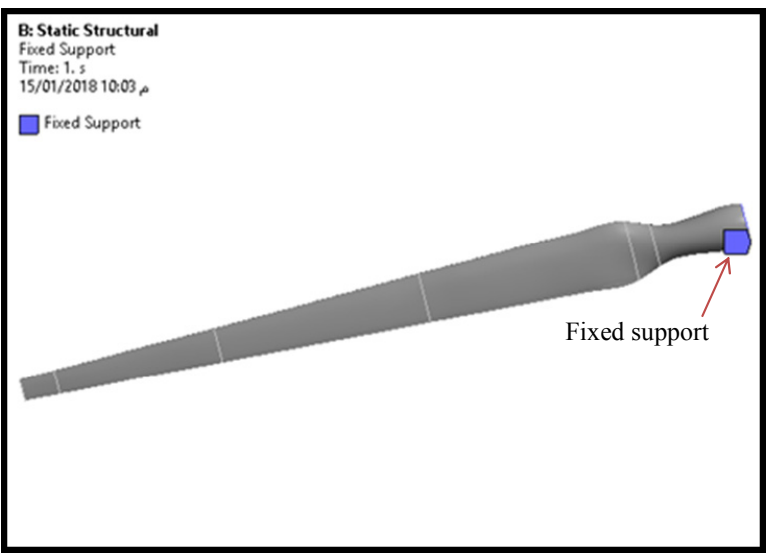

Figure 4. B.C of the wind turbine blade

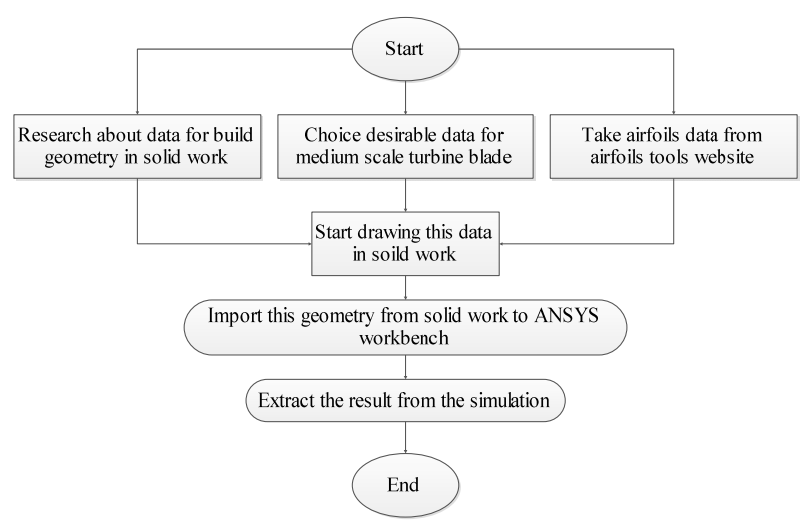

Figure 5. Simple block diagram of simulation process.

The oscillatory movement happens at certain frequencies known as characteristic values or natural frequencies, and it follows the patterns know well-define 
deformation patterns known as characteristic modes or mode shapes. By assuming the external force vector $\{\mathrm{R}\}$ is zero with centrifugal load only; homogenous equation, and the displacements to be harmonic, this equation is specific to free vibration analysis [17], so the motion equation will be as:

$$
[M]\{\ddot{U}\}+[K]\{U\}=0
$$

where $[M]$ is the mass matrix and $\{\ddot{U}\}$ is the acceleration vector.

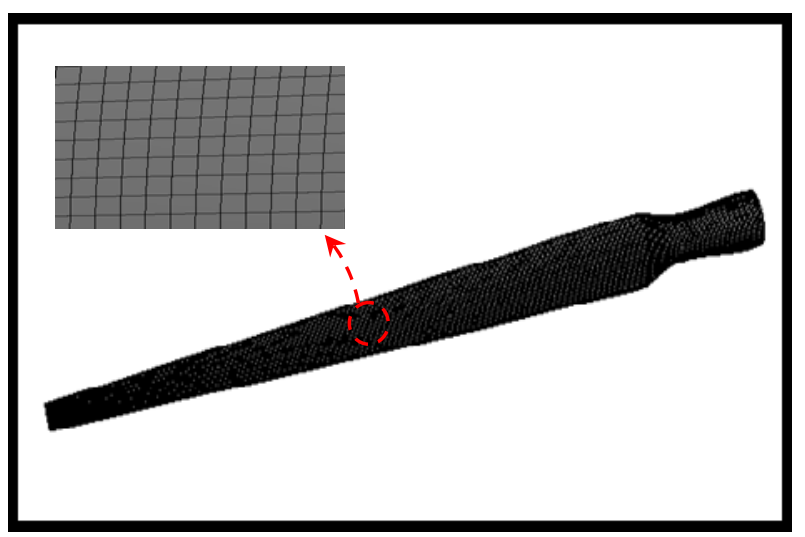

Figure 6. Static structural and Modal mesh for WindPACT 1.5-MW blade.

\section{RESULTS AND DISCUSSIONS}

In this section, the stresses, deformations and natural frequencies of wind turbine blade were presented. It was assumed during the steady-state domain that the wind turbine works at the maximum allowable rotational velocity (20.5 RPM) to produce the designed rating power. Two different materials were used to make the wind turbine blade, where blade- $\mathrm{A}$ is blade which made from the Structural steel and blade-B is a blade made from the $\mathrm{Al} 2024$.

Figures 7-10 illustrate the total deformations and Von-Mises stresses of the wind turbine blades (blade-A and blade-B). It was clear that the distributions of the stresses and deformations of blade- $A$ are similar to blade-B, but there are differences in the values of stresses and deformations between both blades. It can be noticed that the total deformations and stresses of the blade-B are lower than blade-A. The reason of these results that the weight of the blade- $A$ is higher than blade-B, this leads to increase the centrifugal force $\left(\mathrm{F}=\mathrm{mr} \omega^{2}\right)$ that is directly proportional to the total mass of the structure at constant angular speed, therefore the von-Mises stresses and total deformations of the first blade more than the second blade. The maximum value of deformation for both blades occurred at the tip region because it is free to move, whereas the maximum equivalent stress (Von-Mises) occurred at the root region for both blades. Tables 3 and 4 show the deformations and stresses of different angular velocity at which the wind turbine rotates for blades (A and B).

Table 5 listed the first tenth natural frequencies of blade-A and blade-B. It's clear that the values of natural frequencies of the blade- $\mathrm{A}$ are less than in blade-B, because of the structure stiffness of steel more than $\mathrm{Al}$ 2024 (structure stiffness depend of the properties of materials $\mathrm{E}$ and $\rho$ ) and the materials which has higher density give lower natural frequencies. The last four values of the mode shapes were taken into account, as it shown below in the Figures 11-16 for blade-A and blade-B.

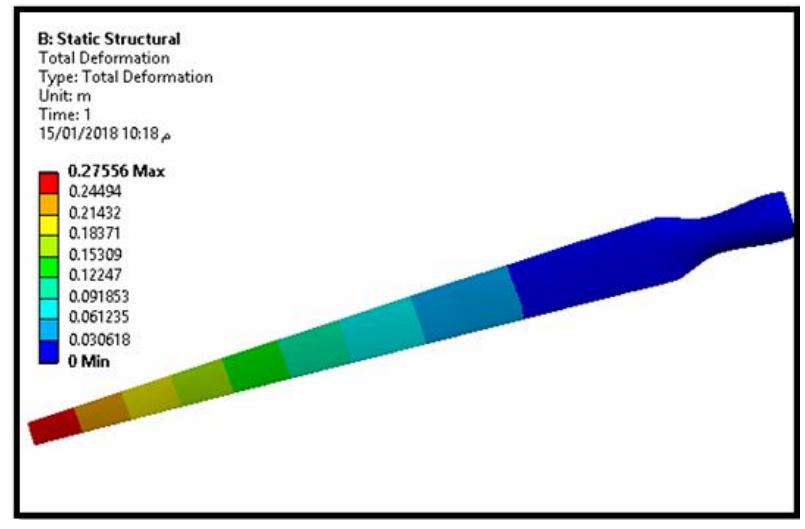

Figure 7. Total deformation of blade (A) at maximum RPM

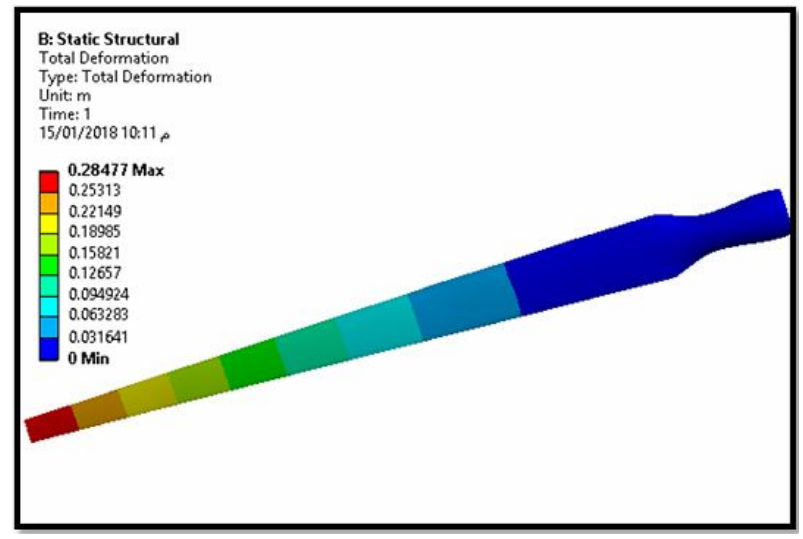

Figure 8. Total deformation of blade (B) at maximum speed

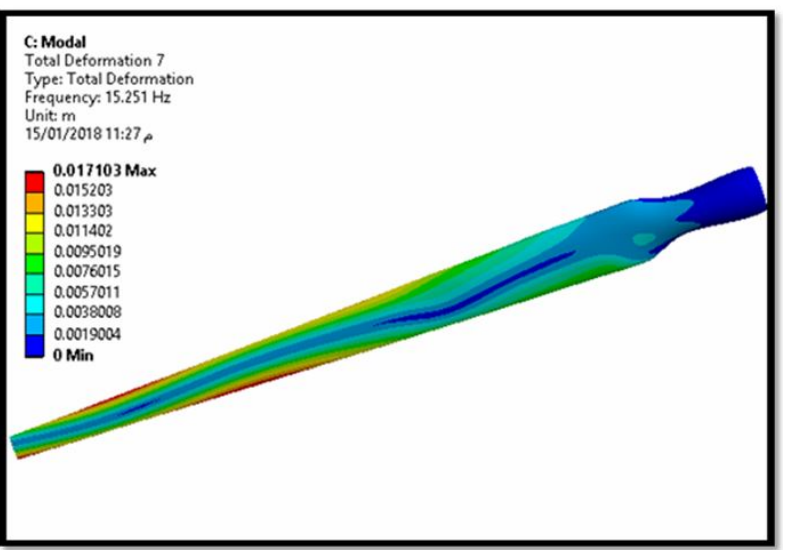

Figure 9. Von-Mises stress of blade (A) at maximum RPM

Table 3. Different values of deformations and stresses for different RPM of blade A

\begin{tabular}{|c|c|c|}
\hline $\begin{array}{c}\text { Rotational } \\
\text { velocity } \\
(\mathrm{RPM})\end{array}$ & $\begin{array}{c}\text { Total } \\
\text { deformation } \\
(\mathrm{mm})\end{array}$ & $\begin{array}{c}\text { Von-mises } \\
\text { stress } \\
(\mathrm{MPa})\end{array}$ \\
\hline 5 & 16.9 & 5.7 \\
\hline 10 & 67.7 & 22.8 \\
\hline 15 & 152.4 & 51.3 \\
\hline 20.5 & 284.7 & 95.8 \\
\hline
\end{tabular}




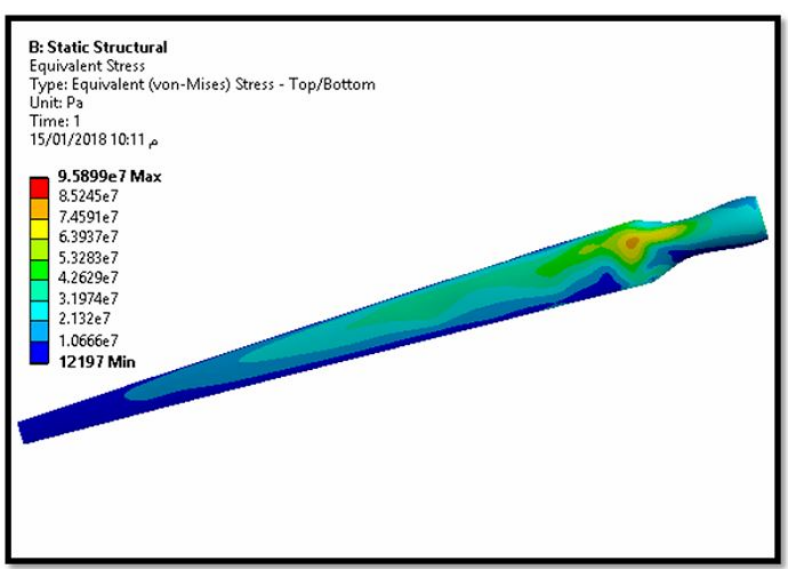

Figure 10. Von-Mises stress of blade (B) at maximum RPM

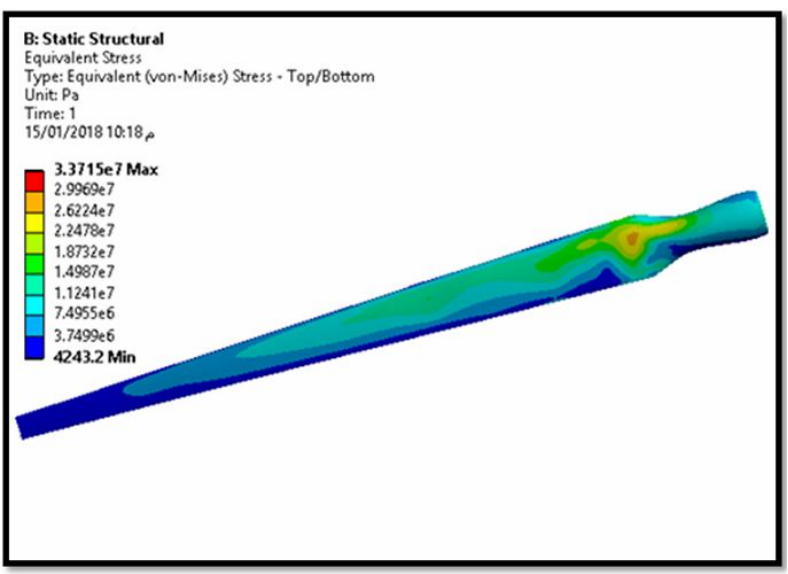

Figure $11.1^{\text {st }}$ mode shape of blade (A)

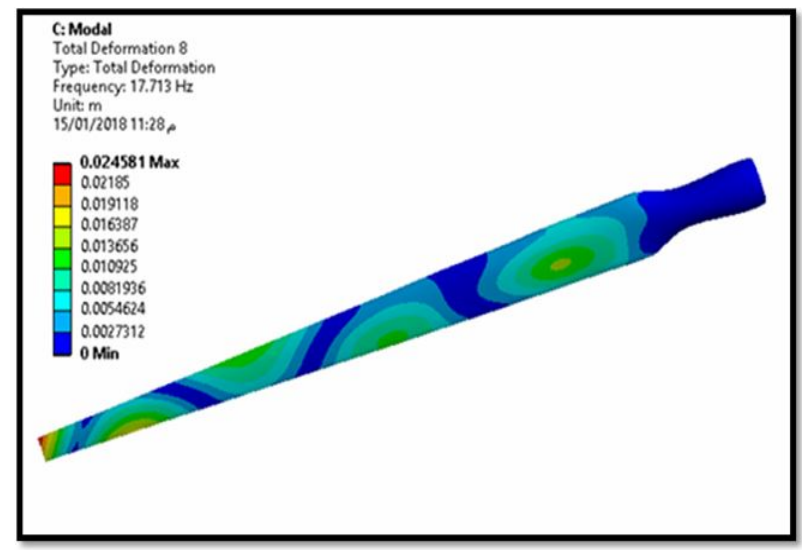

Figure 12. $2^{\text {nd }}$ mode shape of blade (A)

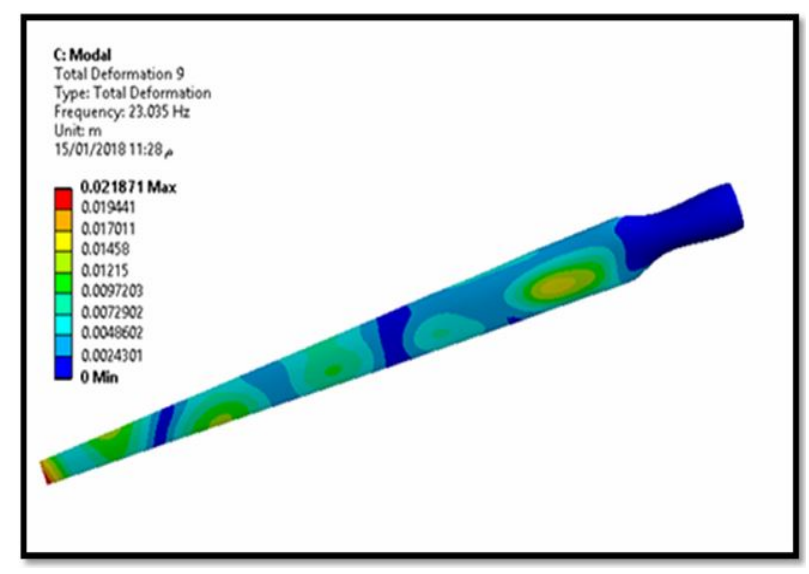

Figure 13. $3^{\text {rd }}$ mode shape of blade (A)

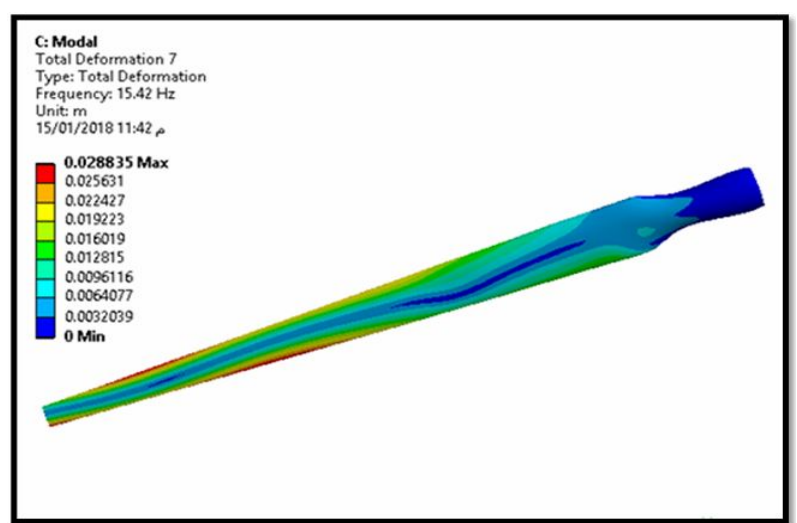

Figure 14. $1^{\text {st }}$ mode shape of blade (B)

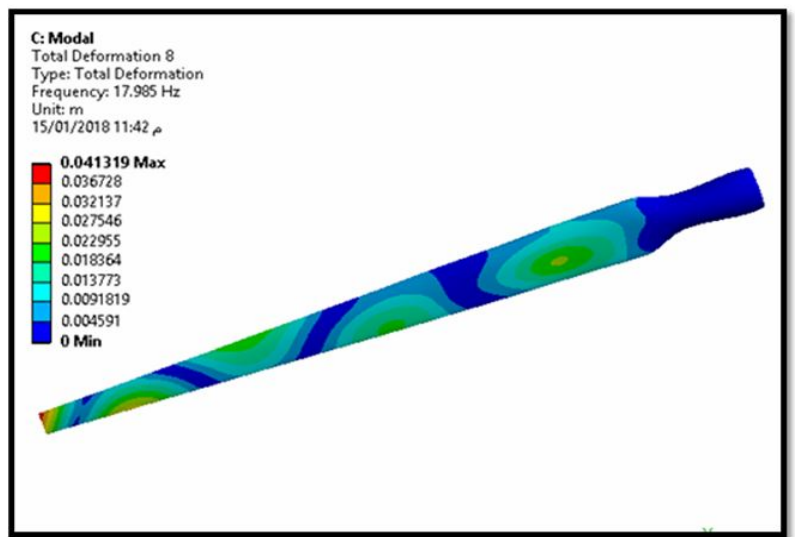

Figure 15. $2^{\text {nd }}$ mode shape of blade (B)

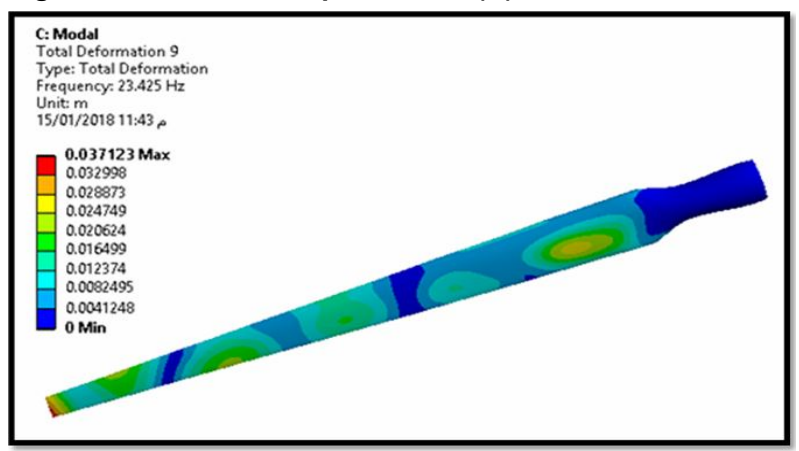

Figure 16. $3^{\text {rd }}$ mode shape of blade (B)

Table 4. Different values of deformations and stresses for different RPM of blade B

\begin{tabular}{|c|c|c|}
\hline $\begin{array}{c}\text { Rotational } \\
\text { velocity } \\
(\mathrm{RPM})\end{array}$ & $\begin{array}{c}\text { Total deformation } \\
(\mathrm{mm})\end{array}$ & $\begin{array}{c}\text { Von-mises } \\
\text { stress } \\
(\mathrm{MPa})\end{array}$ \\
\hline 5 & 16.39 & 2.0053 \\
\hline 10 & 65.572 & 8.0228 \\
\hline 15 & 147.53 & 18.05 \\
\hline 20.5 & 275.56 & 33.715 \\
\hline
\end{tabular}

Table 5. First ten natural frequency of blades $A$ and $B$

\begin{tabular}{|c|c|c|}
\hline Mode shapes & Blade A (HZ) & Blade B (HZ) \\
\hline $1^{\text {st }}$ & 0.72429 & 0.73669 \\
\hline $2^{\text {nd }}$ & 2.2061 & 2.2426 \\
\hline $3^{\text {rd }}$ & 2.7352 & 2.7789 \\
\hline $4^{\text {th }}$ & 6.4562 & 6.5561 \\
\hline $5^{\text {th }}$ & 10.235 & 10.392 \\
\hline $6^{\text {th }}$ & 11.983 & 12.165 \\
\hline $7^{\text {th }}$ & 15.251 & 15.42 \\
\hline $8^{\text {th }}$ & 17.713 & 17.985 \\
\hline $9^{\text {th }}$ & 23.035 & 23.425 \\
\hline $10^{\text {th }}$ & 25.083 & 25.436 \\
\hline
\end{tabular}




\section{CONCLUSIONS AND REMARKS}

The finite element method was used to investigate the behaviour of the wind turbine blade under the steadystate condition. Furthermore, the vibration characteristics of the selected wind blade were studied deeply. 3D model of the wind blade was built using SOLIDWORKS software then exported to ANSYS Workbench software to simulate the steady-state and vibration problems of the wind blade.

It was found that the stresses and deformations decrease when the Aluminium material is used instead of the structural steel material. The reason for these results is the high amount of the centrifugal force of the blade which was made from first material (structural Steel) compared with the other one, which was made from the second type

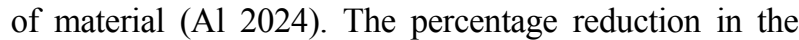
stresses and deformations was found approximately $(64.84 \%$ and $3.23 \%)$ when using the Aluminium material instead of the Structural Steel material.

The values of natural frequencies of the blade made from the first type of material are lower than those made from the second type of material. The values of the natural frequencies depend on the ratio of $(\sqrt{E / \rho})$, where the ratio $(\sqrt{E / \rho})$ of the second type of material to the ratio $(\sqrt{E / \rho})$ of the first type of material is approximately (1.02). Basically, this ratio is based on the cantilever beam formula to find the natural frequency. Therefore, it was found that the ratio of each natural frequency at specific mode shape of blade made from the second type of material to the other one made from the first type of material is approximately 1.02. This paper presented a promising approach to modeling and analyzing the steady-state and vibrational problems of any type of wind turbine blade.

Most of the available studies, which investigated the modeling and stress analysis used very complex approaches which make the modeling of the wind turbine blade consume a lot of time, in addition to finding the solution of the convergence problem. Therefore, this paper is the preliminary work and will be followed by other research to overcome these difficulties, and it presents an approach to modeling and analyzing numerically any type of the blade of wind turbine.

\section{ACKNOWLEDGEMENTS}

The second affiliation of the second author, Asst. Prof. Dr.-Ing. Oday Ibraheem Abdullah, is Hamburg University of Technology (System Technologies and Engineering Design Methodology), Hamburg- Germany.

\section{REFERENCES}

[1] Kumara, A, Dwivedia, A, Paliwala, V, and Patilb, P.P.: Free Vibration Analysis of Al 2024 Wind Turbine Blade Designed for Uttarakhand Region Based on FEA, Procedia Technology, Vol. 14, pp. 336 - 347, 2014.

[2] Rasuo, B., Dinulovic, M., Veg, A., Grbovic, A., Bengin, A.: Harmonization of new wind turbine rotor blades development process: A review,
Renewable and Sustainable Energy Reviews, Vol. 39, pp. 874-882, 2014.

[3] https://www.pinterest.com/thomasholdsw/fans-andturbines/

[4] Technical report: GE 1.5MW Wind Turbine, General Electric Company, USA, 2009.

[5] Abdullah, O.: A Finite Element Analysis for the Damaged Rotating Composite Blade, AlKhawarizmi Engineering Journal, Vol. 17, No. 1, pp. 56-75, 2011.

[6] Abdullah, O.: Vibration Analysis of Rotating PreTwisted Cantilever Plate by Using the Finite Element Method, Journal of Engineering, Vol. 15, No. 1, pp. 3492-3505, 2009.

[7] Al-Ameen E., and Abdullah O.: Vibration of Nonrotating Blades Experimental and Numerical Investigation, Journal of Engineering and Development, Vol. 11, No. 2, pp. 113-124, 2007.

[8] Abdullah, O, Dynamic Analysis of Rotating Cantilever Plates, Al-Khawarizmi Engineering Journal, vol. 2, no. 2, pp. 46-60, 2006.

[9] Garinis, D., Dinulović, M., and Rašuo, B.: Dynamic analysis of modified composite helicopter blade. FME Transactions, Vol. 40, No. 2, pp. 63-68, 2012.

[10] Rasuo, B.: Experimental Techniques for Evaluation of Fatigue Characteristics of Laminated Constructions from Composite Materials: Full-Scale Testing of the Helicopter Rotor Blades, Journal of Testing and Evaluation (JTE), Vol. 39, No. 2, pp. 237-242, 2011.

[11] Rasuo, B.: An Experimental Methodology for Evaluating Survivability of an Aeronautical Constructions from Composite Materials: An Overview, International Journal of Crashworthiness, Vol. 12, No. 1, pp. 9-15, 2007.

[12] Sarangi, S.: Dynamic analysis of a wind turbine blade, M.Sc. thesis, National institute of technology, India, 2014.

[13] Ponta, F. L., Otero, A. D., Lago, L. I., and Rajan, A.: Effects of rotor deformation in wind-turbine performance: the dynamic rotor deformation blade element momentum model (DRD-BEM), Renewable Energy, Vol. 92, pp.157-170, 2016.

[14]Liu, X., Lu, C., Liang, S., Godbole, A., and Chen, Y.: Vibration-induced aerodynamic loads on large horizontal axis wind turbine blades, Applied Energy, Vol. 185, pp.1109-1119, 2017.

[15] Rasuo, B., Bengin, A.: Optimization of Wind Farm Layout, FME Transactions, Vol. 38 No. 3, pp 107114, 2010.

[16] Rasuo, B., Bengin, A., Veg, A.: On Aerodynamic Optimization of Wind Farm Layout, PAMM, Vol. 10, No. 1, pp. 539-540, 2010.

[17] Krishnamurthy, T., and Sesharao, Y.: Design and Dynamic Analysis of Wind Turbine Blade, International Journal of Innovative Research in Science, Vol. 6, No. 9, pp. 18700-18710, 2017.

[18] Malcolm, D. J., and Hansen, A. C.: WindPACT Turbine Rotor Design Study: June 2000-June 2002 
(Revised) (No. NREL/SR-500-32495). National Renewable Energy Lab.(NREL), Golden, CO (United States), 2006.

[19] Schaffer, W. A.: Monopile Foundation Offshore Wind Turbine Simulation and Retrofitting, M.Sc. thesis, South Dakota State University, USA, 2017.

\section{АНАЛИЗА СТАБИЛНОСТИ И ВИБРАЦИЈА КОД ЛОПАТИЦЕ ВЕТРОТУРБИНЕ WIND- PACT 1.5-MW}

\section{Е.А. Казем, О.И. Абдулах, Л.А. Сабри}

У раду се истражује напон и деформација код лопатице ветротурбине у условима стабилног оптерећења и карактеристике вибрација (природних фреквенција и режима рада). Испитује се ветротурбина Wind-PACT $1.5-\mathrm{MW}$ са хоризонталном осом против ветра, која има три лопатице, свака дужине $34,125 \mathrm{M}$ и пречника ротора $70 \mathrm{M}$. Модел турбине је направљен помоћу софтвера SOLIDWORKS и потом експортован у софтвер ANSYS. Нумеричка симулација рада лопатице је изведена помоћу анализе коначних елемената. Стабилност понашања лопатице је истражена у условима номиналне излазне снаге (при максималној брзини ротације од 20,5 РПМ). За израду различитих делова лопатице коришћена су два изотропна материјала (структурни челик - лопатица А и алуминијум Al 2024- лопатица Б) у циљу испитивања утицаја врсте материјала од кога је изграђена лопатица на напон, деформацију и природне фреквенције. Добијени су резултати за фон Мизеов критеријум напона, укупну деформацију и првих десет природних фреквенција код ветротурбине. Утврђено је да се одговор ветротурбине највише побољшава при коришћењу алуминијума Al 2024 уместо структурног челика. 